\title{
FIREARM INJURIES IN THE SPINE. EFFECTIVE STRATEGY FOR DIAGNOSIS AND TREATMENT
}

\author{
LESÕES POR ARMA DE FOGO NA COLUNA. ESTRATÉGIA \\ EFETIVA PARA DIAGNÓSTICO E TRATAMENTO
}

\author{
LESIONES POR ARMA DE FUEGO EN LA COLUMNA. ESTRATEGIA \\ EFECTIVA EN EL DIAGNÓSTICO Y TRATAMIENTO
}

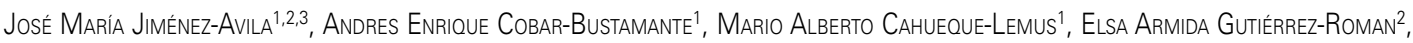 \\ JaIME EduARdo GuZMán-PANTOJA²
}

\begin{abstract}
The incidence of gunshot wounds to the spine on civilians has increased alarmingly and accounts for $13 \%$ to $17 \%$ of all traumatic spinal injuries, placing them in third place among the most frequent mechanisms. However, the management of these injuries is still controversial. At present there is little information on the management of these lesions, conservative treatment (non-surgical) being recommended in most publications. Based on the current literature, we propose a procedural protocol aimed at improving the quickness of management, as well as the prognosis of the patient. For this purpose, once the patient is hemodynamically stabilized, the following should be assessed: 1) Stability; 2) Compressive extrusion; 3) Accommodation or not in the discal space, and 4) Contact with CSF. These points are relevant to make the best decision.
\end{abstract}

Keywords: Wounds gunshot; Spine; Diagnosis; Therapeutics.

\section{RESUMO}

A incidência de lesões por arma de fogo na coluna vertebral na população civil aumentou de modo alarmante e elas representam de $13 \%$ a $17 \%$ de todas as lesões traumáticas da coluna vertebral, o que as coloca em terceiro lugar entre os mecanismos mais frequentes; no entanto, o manejo dessas lesões ainda é controverso. Atualmente, há pouca informação sobre o tratamento dessas lesões, sendo o tratamento consenador (não cirúrgico) recomendado na maioria das publicações. Com base na literatura atual, propomos um protocolo de conduta, que vise melhorar a rapidez dos procedimentos, bem como o prognóstico do paciente. Para esse propósito uma vez que o paciente é estabilizado hemodinamicamente, é preciso avaliar: 1) Estabilidade; 2) Extrusão compressiva; 3) Acomodação ou não no espaço do disco e 4) Se há contato com o LCE. Esses pontos são relevantes para tomar a melhor decisão.

Descritores: Ferimentos por arma de fogo; Coluna vertebral; Diagnóstico; Terapêutica.

RESUMEN

La incidencia de heridas por arma de fuego en la columna vertebral en la población civil, ha aumentado de manera alarmante y representa del 13\% al 17\% de todas las lesiones traumáticas de la columna, colocándolas en la tercera posición entre los mecanismos más frecuentes, sin embargo el manejo de este tipo de lesiones aun es controversial. En la actualidad se cuenta con poca información sobre el manejo de estas lesiones, siendo el tratamiento consenvador (no quirúrgico) recomendado en la mayoría de las publicaciones. Basado en la literatura actual, proponemos un protocolo de actuación, encaminado a mejorar la rapidez en el manejo, así como el pronóstico del paciente. Para este propósito una vez estabilizado el paciente hemodinámicamente, debe de valorarse: 1) Estabilidad; 2) Extrusión compresiva; 3) Alojamiento ó no en el espacio discal y 4) Si existe contacto con LCR. Estos puntos son relevantes para tomar la mejor decisión.

Descriptores:Heridas por arma de fuego; Columna vertebral; Diagnóstico; Terapéutica.

\section{INTRODUCTION}

The incidence of gunshot wounds in the civil population has been increasing at an alarming rate, and this is currently the third most common cause of traumatic spine lesions, resulting in significant costs for the national economy. However, the management of this type of injury is still controversial.

There is currently very little information available about the management of these injuries, with conservative treatment (non-surgical) being recommended in most publications.

A large number of these articles are based on patients injured by military-type firearms, which are not transferable to the civil popu- lation due to differences in the caliber, speed, material, and size of the projectiles. ${ }^{1,2}$

\section{Epidemiology}

Due to the increasing acquisition of firearms, both legally and illegally, they now account for between $13 \%$ and $17 \%$ of traumatic spine injuries, putting them in third place among the most common causes. Car accidents are in first place at $50 \%$, followed by falls from heights in second place at $20 \%$.

There are no accurate statistics for our population. Studies published for North American population report that the average age of

1. Hospital Centro Médico Nacional de Occidente, Guadalajara, Jalisco, Mexico.

2. Instituto Mexicano del Seguro Social, Guadalajara, Jalisco, Mexico.

3. Medical School of the Instituto Tecnológico de Monterrey, Guadalajara, Jalisco, Mexico. 
these victims is between 15 and 34 years, and they are usually male.

Forty-seven percent of the cases are reported as paraplegic and $53 \%$ as quadriplegic, $60 \%$ occur in the thoracic spine and $48 \%$ of the lesions of the cervical spine are complete. ${ }^{3-5}$

\section{Initial Management}

Patient care should include the established routines for trauma, such as ATLS, among others, with a multidisciplinary management approach due to the high probability of injuries to multiple systems.

Following hemodynamic stabilization, the initial management of these patients should include, as a minimum, an assessment of neurological damage and both a complete interrogation about the type of firearm, the time elapsed, the distance between the attacker and the patient, the number of shootings, and a complete physical examination.

Periodic examinations, preferably by the same doctor, should be conducted to evaluate neurological impairment, as this will determine the subsequent treatment. We suggest marking the entry and exit points of the injury with radiopaque staples for evaluation using radiographs to trace the trajectory of the bullet, as this can help predict the lesions that the patient may have suffered. ${ }^{6,7}$

\section{Imaging}

The first studies of choice are simple radiographs, with 2 orthogonal projections, and computed tomography to adequately evaluate the bone damage sustained and the stability of the spine.

When the stability of the spine is in doubt, dynamic radiographic studies can be performed, whenever there is neurological integrity in the patient. 6,7 (Figure 1)

\section{Care of the Wound}

Currently, the trend is towards more conservative management of the wound. Recent publications have shown no difference between the prevention of infection in patients with extensive debridement versus conservative management, combining it with minimally invasive techniques, imaging studies, and antibiotic therapy. Surgical exploration is only recommended when there are signs of significant vascular lesions.

In cases where the wound penetrates contaminated cavities, prolonged antibiotic therapy is recommended. It has been shown

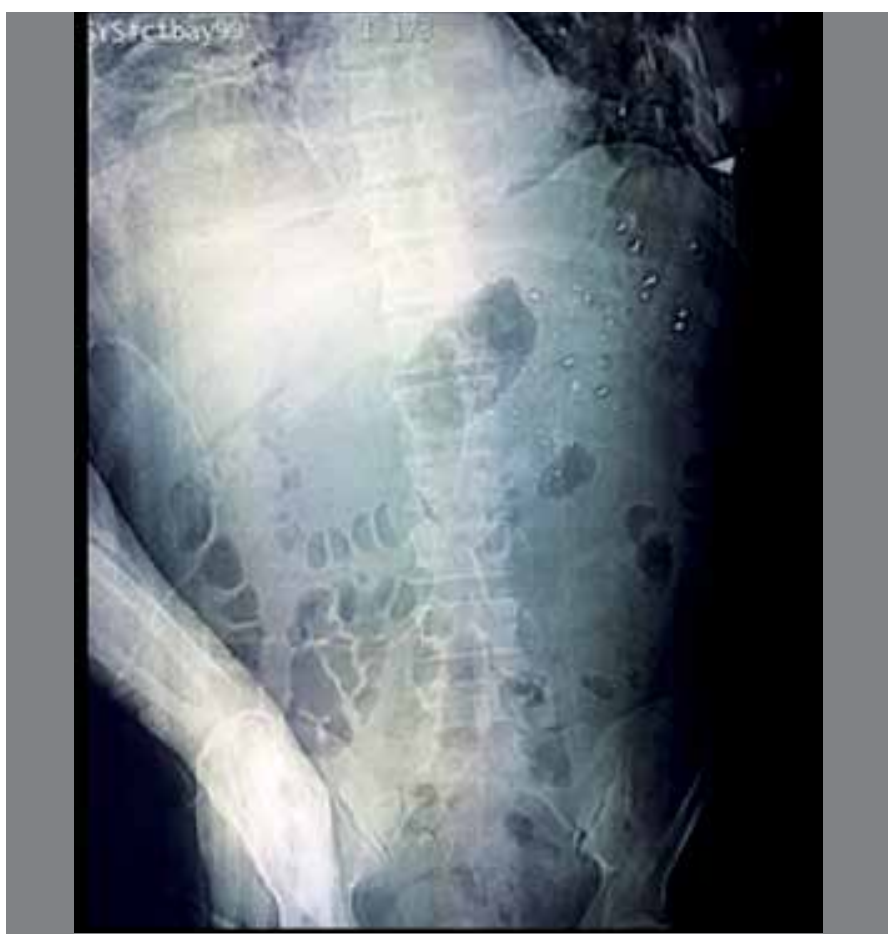

Figure 1. Male patient, 42 years of age, with fracture of T12 impacting the facet joints (unilateral). that if the wound is clean, 3 days of antibiotics are sufficient to prevent complications

Broad-spectrum antibiotic treatment should be started immediately without waiting for culture results, which have been shown to be useless in previous studies, and something that must not be forgotten is anti-tetanus prophylaxis, which is widely recommended. ${ }^{6,7}$

\section{Use of Steroids}

Until recently, the use of steroids for lesions from firearms was undetermined. In a retrospective review of 252 cases with spinal cord lesions secondary to wounds from firearm projectiles treated with methylprednisolone, in accordance with the NACSIS II protocol, it was concluded that there were no changes in the neurological state of the patients, either in those with complete or incomplete lesions.

A study that compared patients who received methylprednisolone or dexamethasone with those that received no treatment showed no difference in terms of neurological deterioration.

Today, the use of steroids should not be considered for the treatment of patients with spinal wounds from firearm projectiles involving spinal cord lesions given that there are reports that mention that they can increase the rate of complications, especially those related to infections..$^{8-10}$

\section{Surgical Decision}

The point at which a decision is made that a lesion requires surgery will depend on the characteristics of the injury, the most important being an evaluation of compressive lesions that can be caused by the presence of bone fragments or "chips within the spinal canal", as well as the existence of epidural bruises. (Figure 2)

\section{Extraction of the Projectile}

In a study of 153 patients with firearm injuries with retention of the projectile, there was a $9.8 \%$ incidence of wound-related sepsis.

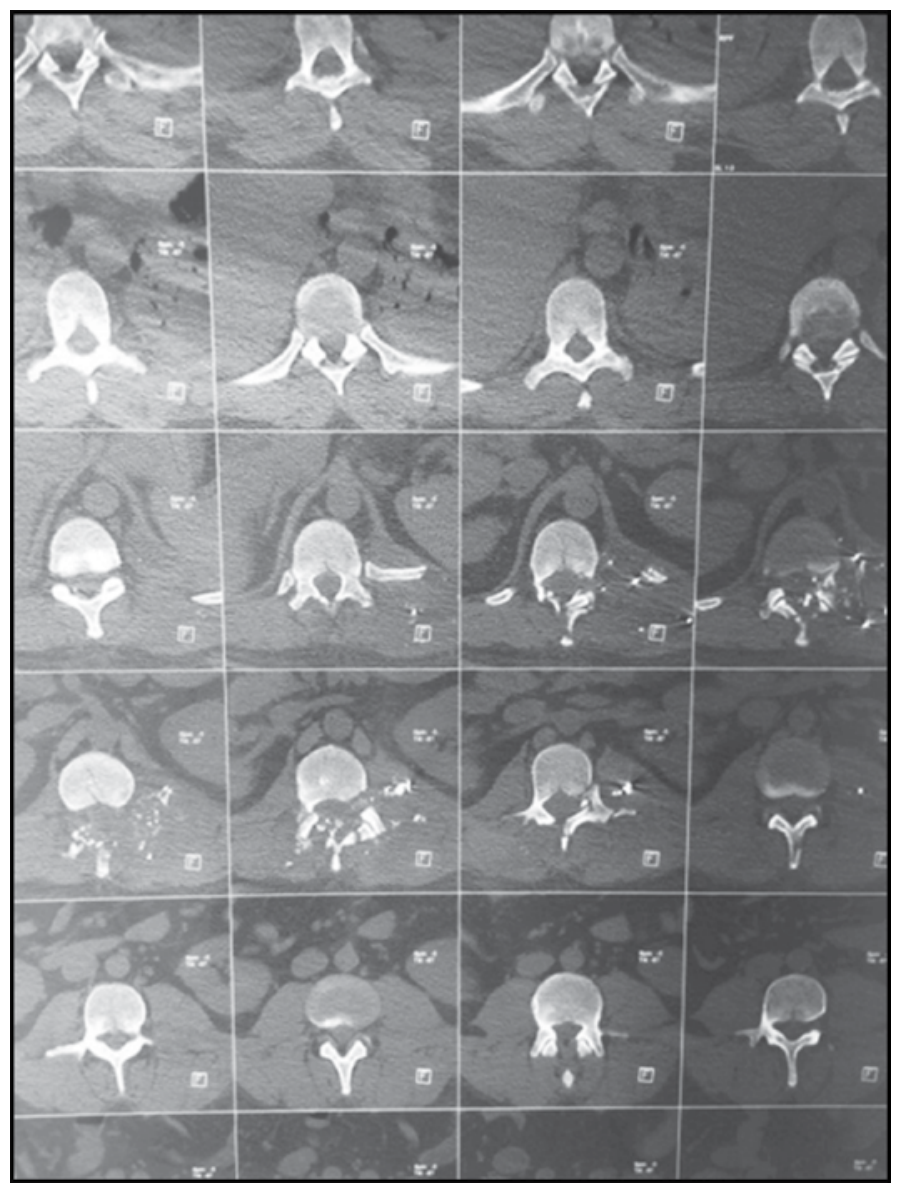

Figure 2. Axial computed tomography - fragmentation of the facet joint of T12. 
In 70 patients, the projectile worked its way out of the body, and in two cases, surgical extraction was indicated, reporting 12.5\% sepsis.

An increase in incidence is linked to the trajectory of the projectile, being greater in patients whose hollow viscera are penetrated before the spine, as well as in those patients who undergo surgical intervention. ${ }^{11-13}$

At the cervical spine level, removal of the foreign body is recommended to achieve the best neurological state possible. It has been shown that the benefits from extracting the projectile are not focused as much on improvement of the spinal lesion as on the possible recovery of the adjacent roots.

Because the thoracic spine is the anatomical region with the lowest spinal cord/spinal canal ratio, any foreign body lodged in this zone can cause compression. In the literature, however, neither the neurological outcomes from surgery in these patients, nor in those with complete spinal cord lesion regardless of the segment, demonstrated benefits. Therefore extraction of the bullet between segments $\mathrm{T} 1$ and $\mathrm{T} 11$ is only performed when there is progressive neurological deterioration.

In the lumbar spine, the spinal canal is wide and the projectile can lodge and migrate. For this reason, extraction is recommended in this region, which includes vertebra T12, in order to prevent an edema rising up from the neurological level. (Figure 3)

Finally, in cases where the neurological damage is complete, surgery is only recommended for removal of the projectile, and only when there is instability of the spine that could cause changes in the biomechanics. ${ }^{11-13}$ (Figure 4)

\section{Stabilization of the Spine}

There are four variables to consider for surgical management: a) the neurological status, b) stability, c) the location of the bullet, and d) the level of the lesion.

Currently, surgical indications include: a) persistent fistula of cerebrospinal fluid, b) spinal instability, c) infection, d) neurological deterioration, and e) arteriovenous fistula, though there are more specific indications depending on the anatomic area affected.

A review of cervical spine injuries from firearms conducted in 2014 reported a higher incidence in levels C-6 and C-7. In that study, the following indications were recommended at the cervical level:

- Injury to 3 levels and injuries to 2 levels plus 1 pedicle (Surgical stabilization);
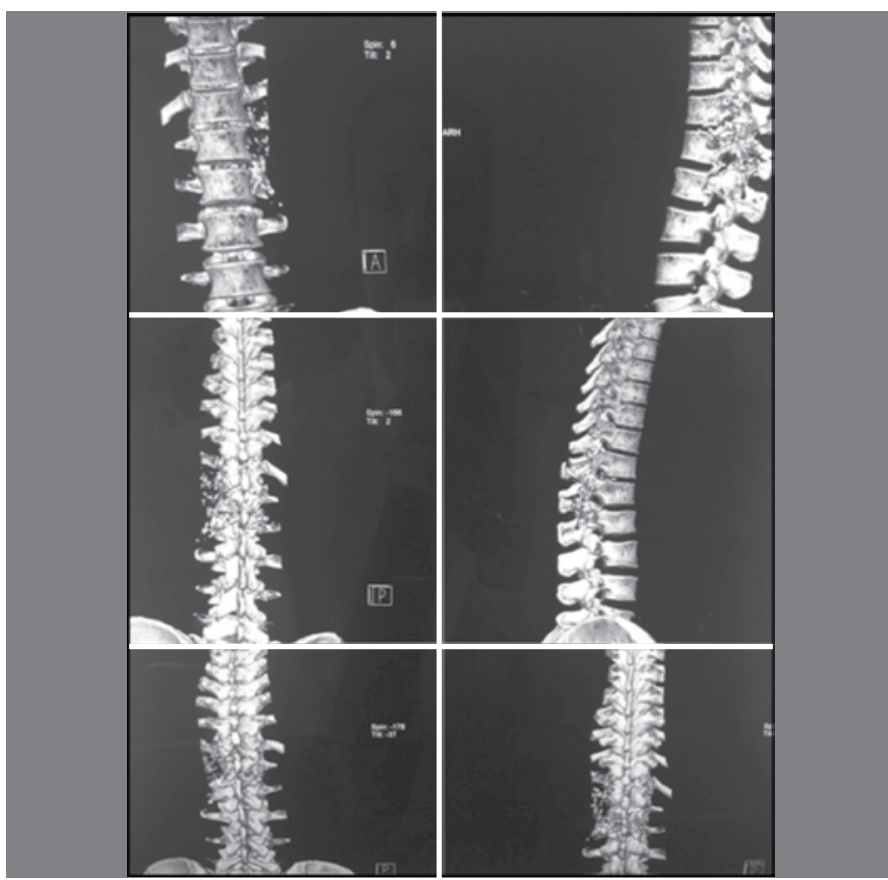

Figure 3. Tomography (reconstruction) - unilateral articular destruction.

- Injury to 1 or 2 levels (Use of orthosis).

- At the thoracolumbar spinal level:

- Injury to 2 or more levels (Thoracolumbar orthosis, fixation, and fusion);

- Injury to 1 level (Observation).

It is worth noting that while the author found no significant difference, in terms of neurological results, between the use of the halo vest and internal fixation, the factors that did present differences were hematological instability, esophageal injury, and thoracic injury at the time of admission. Factors with more long-term influence included persistent infection, the possible need for diaphragmatic pacemakers, and dural lesions without fistula documented in NMR. ${ }^{14-16}$

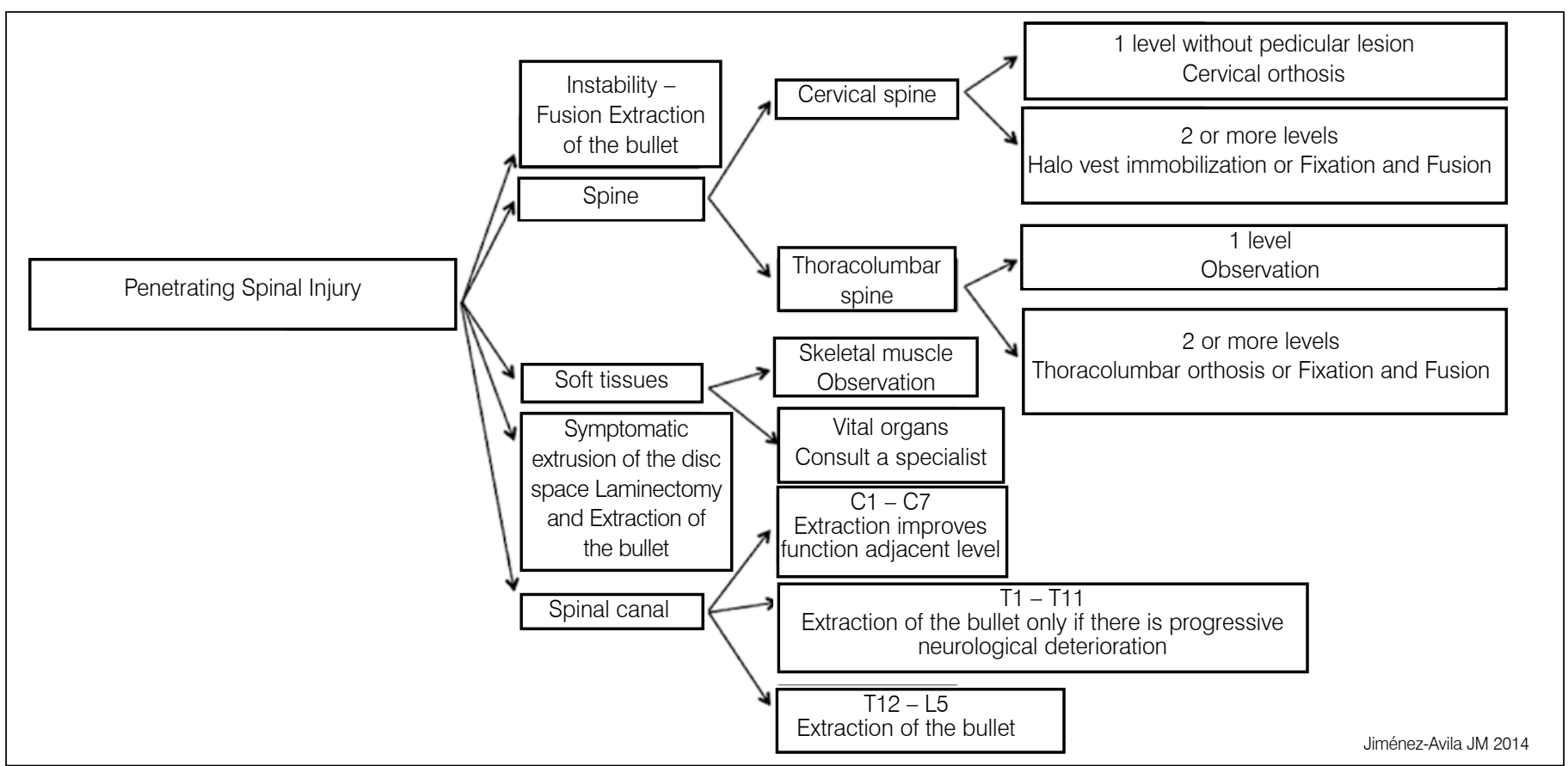

Figure 4. Clinical Practice Guide for surgery decisions (management and extraction of the projectile). "Decision tree". 


\section{Infection of the Wound}

It has been reported that the most common causal agents in these wounds are Gram positive bacteria, accounting for $80 \%$ of the infections, the most common being Staphylococcus aureus and Streptococcus sp. (60\% and $20 \%$, respectively).

Gram negative bacteria account for the other 20\%, among which the most commonly identified are Escherichia coli, Pseudomonas aeruginosa, and Proteus, and the use of cephalosporins continues to be recommended as the initial treatment.

The use of steroids in these cases has been discontinued because it offers no prognostic benefits to the patient and increases the occurrence of complications. ${ }^{17,18}$

\section{FINAL CONSIDERATIONS}

Gunshot wounds of the spine are complex injuries, and their treatment remains controversial. Treatment of the spine by a surgeon depends on the compression from the mechanism of the injury, the different mechanical and biological prognostic factors involved, and the therapeutic options.

Gunshot wounds are considered to be contaminated wounds, therefore the use of antibiotics against Gram + and Gram - bacteria should be standard practice.

It has now been shown that the use of steroids can cause ad- verse events that increase morbidity in this type of patient.

Once patients are hemodynamically controlled, evaluation of the stability of the spine and recovery therapy need to be started, taking the compression status of the spinal cord injury into account in order to assess the prognosis and, even more importantly, making sure that the decisions made are aligned with the Clinical Practice Guidelines.

One of the aspects that occasionally generate debate is whether or not to extract the projectile. The literature provides limited information in this area concerning the approach of bullets lodged in the spine, and the management should be individualized.

Some authors advocate extraction of all bullets, basing their decision on the fact that this minimizes the risk of cerebrospinal fluid leaks; others take a more conservative approach, being more cautious, given the high morbidity rates associated with surgical extraction, and only making a decision for extraction when there is documented progressive neurological damage. There is a need for well-studied protocols that are specific to spinal wounds from firearm projectiles, in order to simplify treatment decisions and further improve the level of care.

All authors declare no potential conflict of interest concerning this article.

\section{REFERENCES}

1. Jiménez-Ávila JM, Calderón-Granados A, Bitar-Alatorre WE. Direct cost of spinal cord injuries. Cir Cir. 2012;80(5):435-41.

2. Jiménez-Avila JM, Alvarez-Garnier JC, Bitar-Alatorre WE. Direct cost of complete cervical spinal cord injury. Acta Ortop Mex. 2012:26(1):10-4

3. Sidhu GS, Ghag A, Prokuski V, Vaccaro AR, Radcliff KE. Civilian gunshot injuries of the spinal cord: a systematic review of the current literature. Clin Orthop Relat Res. 2013;471(12):3945-55.

4. de Barros Filho TE, Cristante AF, Marcon RM, Ono A, Bilhar R. Gunshot injuries in the spine. Spinal Cord. 2014;52(7):504-10.

5. Benzel EC, Hadden TA, Coleman JE. Civilian gunshot wounds to the spinal cord and cauda equina. Neurosurgery. 1987;20(2):281-5.

6. ATLS Subcommittee; American College of Surgeons' Committee on Trauma; International ATLS working group. Advanced trauma life support $\left(A T L S^{\circledR}\right)$ : the ninth edition. J Trauma Acute Care Surg. 2013;74(5):1363-6.

7. Jaiswal M, Mittal RS. Concept of gunshot wound spine. Asian Spine J. 2013;7(4):359-64.

8. Ducker TB, Zeidman SM. Spinal cord injury. Role of steroid therapy. Spine (Phila Pa 1976). 1994;19(20):2281-7.

9. Levy ML, Gans W, Wijesinghe HS, SooHoo WE, Adkins RH, Stillerman CB. Use of methylprednisolone as an adjunct in the management of patients with penetrating spinal cord injury: outcome analysis. Neurosurgery. 1996;39(6):1141-8;
10. Heary RF, Vaccaro AR, Mesa JJ, Northrup BE, Albert TJ, Balderston RA, et al. Steroids and gunshot wounds to the spine. Neurosurgery. 1997;41(3):576-83.

11. Velmahos G, Demetriades D. Gunshot wounds of the spine: should retained bullets be removed to prevent infection? Ann R Coll Surg Engl. 1994;76(2):85-7.

12. Moon E, Kondrashov D, Hannibal M, Hsu K, Zucherman J. Gunshot wounds to the spine: literature review and report on a migratory intrathecal bullet. Am J Orthop (Belle Mead NJ). 2008;37(3):E47-51.

13. Dewan AK, Khanna AJ. Penetrating injuries to the spine. In: Anderson DG, Vaccaro AR editors. Decision Making in Spinal Care. 2nd. New York: Thieme; 2012. p. 567-74.

14. Beaty N, Slavin J, Diaz C, Zeleznick K, Ibrahimi D, Sansur CA. Cervical spine injury from gunshot wounds. J Neurosurg Spine. 2014;21(3):442-9.

15. White AA 3rd, Johnson RM, Panjabi MM, Southwick WO. Biomechanical analysis of clinical stability in the cervical spine. Clin Orthop Relat Res. 1975;(109):85-96.

16. Kupcha PC, An HS, Cotler JM. Gunshot wounds to the cervical spine. Spine (Phila Pa 1976). 1990;15(10):1058-63.

17. Jones RE, Bucholz RW, Schaefer SD, Mumme M, Carder HM. Cervical osteomielitis complicating transpharyngeal gunshot wounds to the neck. JTrauma. 1979:19(8):630-4.

18. Rabinowitz RP, Tabatabai A, Stein DM, Scalea TM. Infectious complications in GSW's through the gastrointestinal tract into the spine. Injury. 2012;43(7):1058-60 